\author{
KAMILLA FREJUSZ \\ COLLEGIUM BOBOLANUM, WARSZAWA \\ ORCID 0000-0001-7620-6599
}

\title{
TOŻSAMOŚĆ KATECHETY I JEGO FORMACJA W DYREKTORIACH Z LAT 1971-2020
}

Problematyka tożsamości podejmowana jest $\mathrm{w}$ wielu dziedzinach nauki: antropologii, socjologii, psychologii czy filozofii. Także w katechezie mowa jest o tożsamości katechety, co znajduje swoje odzwierciedlenie w dokumentach Magisterium Kościoła. Zanim jednak problematyka tożsamości i formacji ukazana zostanie na tle dyrektoriów katechetycznych, najpierw analizie poddane zostanie samo pojęcie tożsamości oraz jej związek z pojęciem formacji. Następnie zaprezentowany zostanie krótki rys historyczny omawianych dokumentów oraz konkretne ich odniesienia do tożsamości i formacji katechetów. Całość zakończona zostanie krótkim podsumowaniem.

Pojęcie tożsamości (identity) wprowadził do nauk społecznych w latach 50. XX wieku psycholog Erik Erikson. Tematyką tą zajmowano się jednak już wcześniej, a czynili to między innymi tacy naukowcy, jak: J. Dewey, Ch. H. Cooley, W. James, J.M. Baldwin,G. H. Mead, R.E. Park, F. Znaniecki. Katarzyna Waszczyńska zwraca uwagę, że angielskie słowo identity $\mathrm{w}$ języku polskim posiada dwa odpowiedniki. Pierwszy oznacza tożsamość jako „bycie tym samym; identycznym”. Drugi odpowiednik wskazuje na społeczny charakter terminu tożsamości i oznacza identyfikację definiowaną jako „stwierdzenie czyjejś tożsamości, ustalenie jednakowości czegoś w porównaniu z czymś, (...) upodabnianie własnej osobowości do jakiegoś wybranego wzorca osobowości (...); proces utożsamienia się (...) z jakimś wzorcem osobowym" ". Ten drugi odpowiednik wydaje się szczególnie odnosić do tożsamości katechety, którą można zaliczyć do kategorii tożsamości społecznej. Zakłada ona bowiem „stałe właściwości charakterystyczne dla osoby bądź grupy umożliwiające ich rozpoznanie"3. Takie ujęcie zwraca uwagę na fakt konstruowania i kreowania własnej tożsamości oraz zakłada możliwość wpływania na jej kształt ${ }^{4}$ To z ko-

\footnotetext{
K. Waszczyńska, Wokół problematyki tożsamości, „Rocznik Towarzystwa Naukowego Płockiego” 6(2014), s. 50.

2 Tamże, s. 50-51.

3 E. Gigilewicz (red.), Encyklopedia katolicka, t. XIX, Lublin 2013, s. 946-948.

4 Por. K. Waszczyńska, Wokół problematyki tożsamości, dz. cyt., s. 49.
} 
lei odbywa się w formacji, która jak czytamy w najnowszym dyrektorium: „jest procesem ustawicznym, który - pod kierownictwem Ducha Świętego i w żywym łonie wspólnoty chrześcijańskiej - pomaga ochrzczonemu ukształtować się, to znaczy odkryć swoją najgłębszą tożsamość. Jest to tożsamość dziecka Bożego pozostającego $\mathrm{w}$ głębokiej komunii $\mathrm{z}$ innymi braćmi. Proces formacji polega na przeobrażeniu osoby przez egzystencjalną interioryzację ewangelicznego przesłania tak, by oświetlało ono i ukierunkowywało jego życie i misję w Kościele"5. Tożsamość katechety jest zatem nierozłączna z procesem formacji. Nie sposób mówić o tożsamości katechety bez odniesienia do tematu formacji. Tożsamość bowiem, jak zaznacza Andrzej Kiciński, jest wieloaspektowa i uwarunkowana zarówno stanem życia w Kościele (biskup, prezbiter, rodzic, osoba zakonna i świecka), jak i sytuacją historyczną (katecheta rodzinny, parafialny i szkolny) ${ }^{6}$.

Tematyka tożsamości i formacji katechety podejmowana jest we wszystkich dokumentach katechetycznych. Próba odpowiedzi na pytania o to, kim jest katecheta, kim powinien się stawać, kim nie jest, czym różni się od innych osób zaangażowanych $\mathrm{w}$ duszpasterst $w^{7}$ - stanowi szczególny przedmiot zagadnień ostatnich dyrektoriów katechetycznych. Idea powstania tychże dokumentów wiąże się z decyzją ojców soborowych, zawartą w Dekrecie o pasterskich zadaniach biskupów z 1965 roku, którzy zalecili stworzenie dyrektorium, mającego pomóc biskupom, a także proboszczom, w sprawowaniu ich urzędu w zakresie katechiza$\mathrm{cji}^{8}$. Pierwsze takie dyrektorium - Directorium catechisticum generale (DCG) - po II Soborze Watykańskim ukazało się w 1971 roku, drugie - Dyrektorium ogólne o katechizacji (DOK) - w 1997 roku, a trzecie - Dyrektorium o katechizacji (DK) - w 2020 roku. Każde z nich, w mniejszym bądź większym stopniu, podejmuje tematykę tożsamości i formacji katechety.

Ogólna instrukcja katechetyczna nie poświęca oddzielnego rozdziału tożsamości katechety. Niemniej w jednym z rozdziałów podejmuje temat formacji katechety, która ma na celu m.in. kształtowanie jego tożsamości. Autorzy dokumentu, obok podkreślenia stałości formacji katechetów, uwypuklają trzy wymiary tej formacji: teologiczno-doktrynalny, antropologiczny oraz metodologiczny. Formacja teologiczno-doktrynalna ma na celu „przyswojenie wiedzy religijnej w takim stopniu, żeby (...) nie tylko przekazać poprawne orędzie ewangeliczne, lecz ponadto przygotować dzieci na przyjęcie tego orędzia w sposób czynny oraz umieć ustalić, co na drodze duchowej osób katechizowanych jest zgodne z wiarą"9. Formacja

\footnotetext{
5 DK 131.

6 Por. A. Kiciński, Formacja katechety na wzór Samuela, w: S. Kulpaczyński (red.), Miejsca katechezy. Rodzina, parafia, szkoła, Lublin 2005, s. 348.

7 Por. R. Szewczyk, Tożsamość katechety w świetle dokumentów Kościoła w latach 1965-1991, Warszawa 1996, s. 13.

8 Por. A. Kiciński, Rozwój dyrektoriów katechetycznych po Soborze Watykańskim II (1971-19972020), „Roczniki Teologiczne” 67(2020)11, s. 6.

9 DCG 112.
} 
antropologiczna, w myśl Instrukcji, odwołuje się do nauk humanistycznych, które kształtują w człowieku jego świadomość samego siebie oraz pozwalają na nabywanie umiejętności do odpowiedniego przekazu głoszonych treści. Formacja metodologiczna natomiast ma odniesienie przede wszystkim do ćwiczeń praktycznych ${ }^{10}$. Zdaniem autorów Instrukcji to właśnie „przez praktykę, przez kierownictwo doświadczonych nauczycieli, przez samo wykonywanie funkcji zdobywa się sztukę przekazywania katechezy, do uformowania której przyczynia się równocześnie zdatność apostolska, znajomość wiary, ludzi i praw kierujących rozwojem czy to poszczególnych osób, czy też wspólnot" ${ }^{\prime 1}$. Oprócz wymienionych wymiarów określających formację katechetów i wpływających jednocześnie na ich tożsamość, Kongregacja ds. Duchowieństwa zwraca uwagę, że zadania powierzane katechetom domagają się od nich „intensywnego życia sakramentalnego i duchowego, praktyki modlitwy, głębokiego zrozumienia wzniosłości chrześcijańskiego orędzia i jego skuteczności w przemianie życia, gorliwej miłości, pokory i roztropności, które pozwalają na owocne działanie Ducha Świętego w osobach katechizowanych"12. Przedstawione wytyczne ukazują zatem katechetę przede wszystkim jako człowieka wykształconego teologicznie, posiadającego odpowiednią znajomość nauk humanistycznych (pozwalających kształtować mu swoje człowieczeństwo oraz pogłębiać znajomość siebie), zaznajomionego z metodologią katechetyczną, a nade wszystko człowieka prowadzącego intensywne życie duchowe.

Dokument kongregacji z 1971 roku regulował kwestie katechezy przez niemal 30 lat. W tym czasie, jak słusznie zauważa Tadeusz Panuś, pojawiło się wiele nowych problemów ewangelizacyjnych, które w Instrukcji były pominięte bądź niewystarczająco uwzględnione. Nade wszystko zaistniała potrzeba ukazania katechezy w wymiarze ewangelizacyjnym. Ponadto pojawiły się nowe dokumenty Magisterium Kościoła dotyczące katechizacji i ewangelizacji, takie jak: Obrzędy chrześcijańskiego wtajemniczenia dorostych (z 1972 roku), Adhortacja apostolska Pawła VI Evangelii nuntiandi (z 1975 roku), Adhortacja apostolska Jana Pawła II Catechesi tradendae (z 1979 roku), Encyklika Jana Pawła II Redemptoris missio (z $1990 \mathrm{roku}$ ), a przede wszystkim opublikowany w 1992 roku Katechizm Kościoła Katolickiego. Zaistniała zatem potrzeba przeredagowania i zaktualizowania Ogólnej instrukcji katechetycznej13. W ten sposób Directorium catechisticum generale zostało zastąpione przez dokument o bardzo podobnej nazwie Direttorio Generale per la Catechesi, zachowujący podstawową strukturę tekstu i terminologię z 1971 roku, uwzględniając jednak dwa nowe wymagania. Po pierwsze, nowe dyrektorium ukierunkowało katechezę w ramach ewangelizacji na podstawie adhortacji Evangelii

\footnotetext{
10 Por. tamże.

11 Tamże 113.

12 Tamże.

13 T. Panuś, Geneza i główne wskazania Dyrektorium ogólnego o katechizacji z 1997, „Studia Katechetyczne" 13(2017), s. 17.
} 
nuntiandi i Catechesi tradendae. Po drugie, uwzględniło treści wiary zaproponowane przez Katechizm Kościoła Katolickiego ${ }^{14}$. Nowy dokument, promulgowany podczas Międzynarodowego Kongresu Katechetycznego w październiku w 1997 roku nosi nazwę Dyrektorium ogólne o katechizacji. Podobnie jak to było w przypadku Instrukcji, jego autorem jest Kongregacja ds. Duchowieństwa.

Temat tożsamości i formacji katechety zajmuje o wiele więcej miejsca w Dyrektorium ogólnym o katechizacji niż w Instrukcji. Tematyce tej poświęcony jest jeden z rozdziałów piątej części dyrektorium zatytułowany „Formacja do posługi katechetycznej”. Analizując tematykę tożsamości i formacji katechety w kontekście kolejnego dyrektorium, łatwo dostrzec liczne odwołania do wcześniejszej Instrukcji. Niemniej, jak zauważa Andrzej Kiciński, „nowości jest dużo. (...) Jest to z pewnością pierwszy $\mathrm{w}$ historii dokument, gdzie jeden z rozdziałów jest całkowicie poświęcony inkulturacji. (...) Jest też opracowanych więcej miejsc i dróg katechezy. Katecheza dorosłych - nawet strukturalnie wymieniona na pierwszym miejscu - a potem katecheza dzieci i młodzieży stała się punktem wyjścia i pilną potrzebą naszych czasów. Nowością jest również spojrzenie na katechezę w sytuacji pluralizmu i złożoności oraz, co szczególnie ważne dla sytuacji w Polsce, zaproponowano nowy stosunek katechezy do nauczania religii katolickiej w szkole"15.

Również w kontekście formacji odnajdujemy nowe wskazania i pogłębione analizy. Po pierwsze, omawiając kryteria określające formację katechetów autorzy Dyrektorium podkreślają dostosowanie formacji do potrzeb ewangelizacyjnych. Te z kolei wymagają, aby katecheci wyróżniali się „głęboką wiarą, wyrazistą tożsamością chrześcijańską oraz głęboką wrażliwością społeczną" "16. Po drugie, powinni być równocześnie „nauczycielami, wychowawcami i świadkami. (...) Powinni (...) umieć połączyć poznawczy i znaczący wymiar wiary, ortodoksję i ortopraksję, zmysł eklezjalny i społeczny"17. Formacja katechetów, przedstawiana we wcześniejszym dokumencie w trzech wymiarach: teologiczno-doktrynalnym, antropologicznym oraz metodologicznym, w świetle Dyrektorium ogólnego o katechizacji rozpatrywana jest w podobny (choć nieco szerszy i pogłębiony sposób) w wymiarach: być, wiedzieć, umieć działać ${ }^{18}$. Wymiary te odnajdą swoje odzwierciedlenie również w kolejnym, najnowszym dyrektorium. W pewien sposób "na stałe” wpisują się one w tożsamość i formację katechetów, niezależnie od zachodzących zmian w oświacie, czy też pojawiających się reform ${ }^{19}$.

14 Por. Kiciński, Rozwój dyrektoriów katechetycznych po Soborze Watykańskim II (1971-1997-2020), dz. cyt., s. 15.

15 Tamże, s. 17.

16 DOK 237.

17 Tamże.

18 Tamże 238.

19 Por. K. Frejusz, Katecheta wobec reformy oświaty - „być, wiedzieć, umieć działać”, w: J. Kowalczyk, A. Rayzacher-Majewska (red.), Idźmy naprzód z nadzieja! Katechetyczne aspekty reformy oświaty, Diecezjalne Centrum Edukacyjne, Legnica 2017, s. 53-69. 
Najgłębsza formacja, zdaniem autorów Dyrektorium, odnosi się właśnie do tożsamości katechety, do „samego być katechety, do jego wymiaru ludzkiego i chrześcijańskiego"20. Ma ona zatem pomagać mu w dojrzewaniu jako osobie, jako wierzącemu i jako apostołowi. Widoczne tutaj akcenty położone są na formację ludzką, chrześcijańską i apostolską. W pierwszym aspekcie autorzy dyrektorium podkreślają konieczność osiągniecia dojrzałości ludzkiej, na podstawie której działalność katechetyczna „pozwoli katechecie wzrastać w równowadze uczuciowej, w sensie krytycznym, w jedności wewnętrznej, w zdolności relacji i dialogu, w duchu konstruktywnym i w pracy grupowej" ${ }^{21}$. Odwołując się do dokumentu Kongregacji ds. Ewangelizacji Narodów Guida per i catechisti z 1993 roku, autorzy Dyrektorium wymieniają następujące jakości ludzkie: „łatwość relacji ludzkich i dialogu, zdolność komunikacji, gotowość do współpracy, funkcja przewodniczenia, poprawność ocen, zrozumienie i realizm, zdolność do pocieszania i budzenia nadziei”"22. Jerzy Smoleń w jednym ze swoich artykułów poświęconych formacji ludzkiej, zwraca $\mathrm{z}$ kolei uwagę, że formacja ludzka powinna być tak organizowana i prowadzona, by wytyczała drogę do dojrzałej osobowości. Ta, jego zdaniem, wyraża się następującymi postawami: akceptacją siebie, integracją osobowości, hierarchią wartości, postawą wobec życia, rozumieniem innych, dojrzałością uczuciową, gotowością do poświęceń, twórczością i szerokością zainteresowań, realnym poznaniem świata ${ }^{23}$. Formacja ludzka wydaje się szczególnie istotna w kontekście tożsamości katechety. Jak zauważa Mirosław Gogolik, to właśnie „w formacji ludzkiej należy (...) zwrócić uwagę na ważność tożsamości osobowej katechety. Jednym bowiem $\mathrm{z}$ jego zadań jest prowadzenie młodych do stawania się «pełnowartościowymi» ludźmi. To prowadzenie może się odbyć dzięki temu, że sam katecheta przez odpowiednią formację ludzką stanie się człowiekiem w pełni funkcjonującym, jest sobą"24.

Formacja chrześcijańska z kolei, w świetle Dyrektorium ogólnego o katechizacji, ma na celu troszczyć się o to, aby katechizacja karmiła wiarę katechety, prowadząc do jej wzrostu. Ma zatem ożywiać jego duchowość w taki sposób, aby jego działalność była poświadczona jego życiem. Ma on zatem być nie tylko przekazicielem konkretnych prawd, ale także świadkiem wiary. Świadek, jak słusznie podkreśla Marek Mendyk, to ktoś, „kto kocha i fascynuje miłością. To ostatecznie świadek tego Boga, który jest miłością i na którego obraz i podobieństwo został stworzony każdy z wychowanków. Taki katecheta rozumie, że tylko sam wychowanek - poprzez spotkanie z Bogiem, z bliźnimi i z samym sobą - może odkryć sens swojego życia, czyli swój niepowtarzalny sposób włączenia się w Bożą i ludzką historię

\footnotetext{
20 DOK 238.

21 Tamże 239.

22 Tamże, przypis 17.

23 Por. J. Smoleń, Formacja ludzka katechetów, „Paedagogia Christiana” 2(2009)24, s. 153-155.

24 M. Gogolik, Znaczenie formacji duchowej w procesie postugi słowa, „Pedagogia Ojcostwa” 1(2010), s. 237.
} 
miłości" ${ }^{25}$. Katecheta, który jest świadkiem, musi zatem mieć świadomość apostolską. Dlatego też kolejny wymiar formacji odnosi się do ożywiania świadomości apostolskiej oraz jego zmysłu ewangelizatora. Jako najlepszy sposób umacniania tej świadomości apostolskiej autorzy dyrektorium wskazują utożsamienie się z postacią Jezusa Chrystusa, nauczyciela i wychowawcy uczniów ${ }^{26}$.

Kolejny wymiar formacji dotyczy wiedzy katechety. Wymiar ten „przeniknięty podwójną wiernością orędziu i osobie ludzkiej, wymaga, aby katecheta znał odpowiednie orędzie, które przekazuje, a zarazem adresata, który je otrzymuje, jak również kontekst społeczny, w którym żyje" ${ }^{27}$. Wymogom tym powinna sprostać formacja biblijno-teologiczna, która winna być formacją o charakterze syntetycznym, powinna być bliska doświadczeniu ludzkiemu, a zatem zdolna do połączenia różnych aspektów orędzia chrześcijańskiego z konkretnym życiem. Znajomości adresata i kontekstu społecznego powinna sprzyjać formacja uwzględniająca nauki humanistyczne, a zatem zaznajamiająca katechetę z podstawowymi elementami psychologii, dynamizmami psychologicznymi, strukturą osobowości, potrzebami i aspiracjami ludzkiego serca, etapami życia ludzkiego oraz psychologią religijną. Istotne, zdaniem autorów Dyrektorium, jest także uwzględnienie w formacji nauk społecznych, które są pomocne w poznaniu kontekstu społeczno-kulturowego oraz w ocenie warunków socjologicznych, ekonomicznych i kulturowych. Nauki te dostarczają narzędzi poznawczych pozwalających na ustalenie, w jakim zakresie poszczególne fakty życia wspólnotowego mogą mieć wpływ na proces ewangelizacjii ${ }^{28}$.

Ostatni z wymiarów formacji, prezentowany w Ogólnym dyrektorium o katechizacji, wynikający z faktu, że katecheza jest aktem komunikacji, dotyczy umiejętności działania. Zakłada on doprowadzenie do dojrzałości zdolności wychowawczych, do których zalicza się m.in: zwracanie uwagi na osobę, umiejętność interpretowania stawianych pytań wychowawczych oraz odpowiadania na nie, sztukę prowadzenia grupy osób do dojrzałości, jak i inicjatywę uaktywniania procesów rozumienia. Formacja ta ma pomóc katechecie w umiejętnym programowaniu działań wychowawczych, uwzględniając okoliczności, opracowując realistyczny program, aby w końcu po jego realizacji umieć krytycznie go ocenić. Ma także uzdolnić katechetę do animowania grupy oraz roztropnego korzystania z technik animacji grupy. Ten wymiar formacji powinien być szczególnie bliski praktyce, od której wychodzi i jednocześnie do niej powinien zmierzać ${ }^{29}$. Pomocne w rozumieniu tego wymiaru formacji wydaje się porównanie katechety do nauczyciela muzyki. Nauczyciel ten

25 M. Mendyk, Katecheta-nauczyciel, wychowawca, świadek. Jego misja w warunkach nowej ewangelizacji, „Legnickie Studia Teologiczno-Historyczne” 10(2007), s. 116.

26 Por. DOK 239.

27 DOK 238.

28 Por. DOK 240-242.

29 Por. DOK 244-245. 
może tłumaczyć i wyjaśniać zasady gry, ale w ten sposób nie nauczy jeszcze swoich uczniów grać; musi dopiero sam pokazać, jak się to robi ${ }^{30}$.

Oprócz wymiarów formacji „być, wiedzieć, umieć działać” autorzy Dyrektorium zwracają również uwagę na konieczność formacji katechetów w ramach wspólnot chrześcijańskich. W takich wspólnotach katecheci mogą doświadczać i pogłębiać swoje powołanie oraz pielęgnować swój zmysł apostolski. Wspólnoty chrześcijańskie umacniają katechetów w ich powołaniu eklezjalnym poprzez ożywianie świadomości tego, że są posłani przez Kościół. Są one zatem wyjątkowym środkiem formacyjnym, który nie tylko uwrażliwia ich na katechezę, ale także dostarcza formacji doktrynalnej ${ }^{31}$. W tym kontekście warto również podkreślić, że katecheta oprócz osobistej formacji w ramach wspólnot chrześcijańskich, powinien także zachęcać katechizowanych do włączania się w takie wspólnoty, „przypominać o szerokich możliwościach, jakie one niosą dla rozwoju religijnego i wychowawczego. Przystąpienie do grupy stwarza ogromne szanse podjęcia przez młodego człowieka świadomej, osobistej decyzji, przez którą opowiada się za Jezusem i dla Niego postanawia podjąć określone starania. Wydaje się to istotnym elementem wspierającym cały proces katechetyczny"32.

Zarówno Ogólna instrukcja katechetyczna z 1972 roku, jak i Dyrektorium ogólne o katechizacji z 1998 roku poświęcają wiele miejsca (choć w przypadku Instrukcji nie zawsze explicite) tematyce tożsamości i formacji katechety. Warto podkreślić, że dokumenty te zgodnie prezentują tożsamość i formację katechety wokół pojęć dojrzałości ludzkiej, chrześcijańskiej i apostolskiej, formacji biblijno-telogicznej, pedagogicznej oraz formacji w ramach wspólnot chrześcijańskich. O ile Instrukcja była odpowiedzią na wydarzenie eklezjalne, jakim była reforma i odnowa zaproponowana podczas Vaticanum II, o tyle odniesieniem dla dyrektorium z 1997 roku były synody, poświęcające dużo miejsca znaczeniu katechezy, a przede wszystkim adhortacja Catechesi tradendae oraz ukazanie się Katechizmu Kościoła Katolickiego. Dokumenty te miały na celu odpowiadać na znaki czasu w szybko zmieniającym się świecie oraz dostosować do tych odpowiedzi formację, która kształtuje tożsamość katechetów ${ }^{33}$.

Najnowsze Dyrektorium z 2020 roku nie stanowi odmiennego czy też odbiegającego w swych założeniach i treściach dokumentu, w stosunku do poprzednich dyrektoriów. Jest raczej dynamicznym rozwinięciem dwóch wcześniejszych tekstów, z którymi zachowuje ciągłość. Niemniej ważnym podkreślenia jest fakt, że przygotowaniem tekstu nie zajmowała się, jak poprzednimi dyrektoriami, Kongregacja

\footnotetext{
30 Por. J. Misiewicz, Tożsamość katechety a skuteczność przepowiadania wiary, „Wrocławski Przegląd Teologiczny" 5(1997)2, s. 115.

31 Por. DOK 246-247.

32 R. Szewczyk, Osobowość nauczyciela religii, „Studia Katechetyczne” 7(2010), s. 233.

33 Por. A. Kiciński, Rozwój dyrektoriów katechetycznych po Soborze Watykańskim II (1971-19972020), dz. cyt., s. 25.
} 
ds. Duchowieństwa, lecz Papieska Rada ds. Nowej Ewangelizacji. Już w samym Wstępie dokumentu abp Rino Fisichella podkreśla, że jednym z najważniejszych odniesień dla dyrektorium był Synod poświęcony Nowej ewangelizacji dla przekazu wiary chrześcijańskiej oraz Adhortacja apostolska papieża Franciszka Evangelii gaudium. Jego zdaniem, trzy ostatnie dyrektoria „łączy to, że wszystkie upominają się o te same cele i zadania dla katechezy. Różni je natomiast odmienny kontekst historyczny i uaktualnione Magisterium. Pierwszą instrukcję i kolejne dyrektorium dzieli dwadzieścia sześć lat. Od tego drugiego dokumentu do naszego minęły dwadzieścia trzy. Chronologia wskazuje poniekąd na historyczną dynamikę, z jaką trzeba się zmierzyć. Z głębszego spojrzenia na kontekst kulturowy wyłania się szereg nowych kwestii, do których przeżycia Kościół jest wezwany"34. W jaki sposób te nowe kwestie przekładają się na kształtowanie tożsamości katechety? Czy niosą nowe wyzwania i zadania? Wokół jakich treści skupiać się ma współczesna formacja katechety?

Jednym z najistotniejszych aspektów nowego Dyrektorium, które odnosi się do tożsamości katechety, jest jego kerygmatyczny i ewangelizacyjny charakter. Kryterium, które przyświecało refleksji i opracowaniu najnowszego Dyrektorium, osadzone jest w słowach papieża Franciszka, zawartych w Evangelii gaudium: „Odkryliśmy, że także w katechezie fundamentalną rolę odgrywa pierwsze przepowiadanie lub «kerygma», która powinna zajmować centralne miejsce w działalności ewangelizacyjnej i w każdej próbie odnowy kościelnej. [...] Gdy mówimy, że to orędzie jest "pierwsze», nie oznacza to, że jest na początku, a potem się o nim zapomina, albo zastępuje się je innymi treściami, które je przewyższają. Jest pierwszym w sensie jakościowym, ponieważ jest głównym orędziem, tym, do którego trzeba stale powracać i słuchać na różne sposoby i które trzeba stale głosić podczas katechezy w tej czy innej formie, na wszystkich jej etapach i chwilach" ${ }^{\text {. }}$. Widoczny prymat kerygmatu oraz katecheza kerygmatyczna nie odbiera jednocześnie wartości mistagogii ani też świadectwu miłości miłosiernej. Niemniej to właśnie kierunek kerygmy i ewangelizacji wydaje się wskazywać punkty, wokół których Dyrektorium omawia tożsamość i formację katechety. Trzy części, które składają się na Dyrektorium o katechizacji, zawierają bowiem głównie treści opisujące drogę katechezy podporządkowanej prymatowi ewangelizacji. $\mathrm{O}$ wiele obszerniej niż w poprzednich dokumentach katechetycznych, potraktowany został także temat formacji katechetów. Naglące bowiem, zdaniem autorów najnowszego Dyrektorium, „wydaje się przywrócenie wymiaru posługi ich działalności w chrześcijańskiej wspólnocie. Zresztą, jedynie katecheci, którzy przeżywają swoją posługę jako powołanie, skutecznie przyczyniają się do katechizacji”"36.

\footnotetext{
${ }^{34}$ DK, Wstęp, s. 9.

35 EG 164.

36 Por. DK, Wstęp, s. 11.
} 
Stąd też tożsamość katechety jest, jak wskazuje sama nazwa podrozdziału najnowszego Dyrektorium, nierozłączna z pojęciem powołania. Katecheta to „chrześcijanin, który otrzymuje szczególne powołanie od Boga. Przyjęte w wierze, uzdalnia go ono do posługi przekazywania wiary i dawania początku chrześcijańskiemu życiu"37. Pojęcie powołania często odnoszone jest do kwestii wykonywanego zawodu, spełnianych obowiązków i posług. Sformułowanie to przeniesione na płaszczyznę religijną przyjmuje wymiar personalny i zawsze zawiera odniesienie człowieka do Bożej woli, planów Bożych, które ma on zrealizować w swoim życiu ${ }^{38}$. Istotą tożsamości katechety jest zatem jego odkrycie i przyjęcie powołania. Na jego mocy katecheta jest „świadkiem wiary i strażnikiem pamięci o Bogu”, „nauczycielem i mistagogiem” oraz "towarzyszem i wychowawcą tych, którzy zostali mu przez Kościół powierzeni" ${ }^{39}$. W kontekście tych wyzwań Dyrektorium formułuje także konkretne wskazania formacyjne.

Bycie świadkiem wiary i strażnikiem pamięci o Bogu, zgodnie z ewangelizacyjnym charakterem dyrektorium, stanowi pierwszorzędne wyzwanie dla kształtowania tożsamości katechety. Postawa świadka wydaje się pierwotna i podstawowa dla realizacji katechezy ${ }^{40}$. Warunkiem spełnienia tego zadania jest osobiste doświadczenie dobra i prawdy Ewangelii w spotkaniu z Jezusem. Katecheta tylko wówczas będzie „znakiem dla innych”, kiedy będzie dawał świadectwo własnego „nowego” życia $\mathrm{w}$ Jezusie ${ }^{41}$. Cele związane z przekazywaniem świadectwa zostaną osiągnięte, zdaniem Zbigniewa Marka, „dopiero wówczas, gdy odkrywane wartości religijne staną się osobistymi wartościami, tzn. kiedy ich odbiorca zacznie się z nimi identyfikować i nazywać je swoimi. Innymi słowy, może to nastąpić wówczas, kiedy sam przeżyje przekazywaną mu prawdę religijną" ${ }^{22}$. Aby to było możliwe, zamiast „tylko mówić o Bogu i uczyć o Nim, należy Go uczniom ukazywać, stawiać ich w Jego obecności i umożliwiać spotkanie z Nim. (...) Przez to osobowe obcowanie ze Słowem Bożym łatwiej i żywiej uświadamiamy sobie wielkość i miłość Boga niż przez naukowe wyjaśnianie pojęć i rozumowanie" ${ }^{43}$. Katecheta ma zatem zawsze nauczać w oparciu o własne doświadczenie Boga, doświadczenie relacji z Nim ${ }^{44}$.

Przygotowanie katechety do bycia świadkiem wiary i strażnikiem pamięci o Bogu autorzy Dyrektorium o katechizacji umieszczają w wymiarze „bycia i umiejętności bycia z". Wymiar ten obejmuje (podobnie jak we wcześniejszym

\footnotetext{
37 DK 110.

38 Por. M. Gogolik, Znaczenie formacji duchowej w procesie posługi słowa, dz. cyt., s. 242.

39 DK 113.

40 Por. R. Szewczyk, Tożsamość katechety w świetle dokumentów Kościoła w latach 1965-1991, dz. cyt., s. 176.

41 Por. DK 113.

42 Z. Marek, Katecheza Kościoła w świetle Dyrektorium ogólnego o katechizacji, „Collectanea Theologica", 68(1998)3, s. 172.

43 M. Finke, Pedagogika wiary, Poznań 1996, s. 13.

44 Por. DK 135.
} 
Dyrektorium) dojrzałość ludzką, chrześcijańską i misyjną (nazywaną w poprzednim Dyrektorium apostolską). Formacja ma zatem pomóc katechetom postrzegać własną działalność katechetyczną jako sposobność do wzrostu w wymiarze ludzkim i chrześcijańskim. W oparciu o dojrzałość ludzką, katecheta ma stale „rozwijać równowagę uczuciową, krytycyzm, wewnętrzną spójność i wolność, w relacjach, które wspierają i wzbogacają wiarę" 45 .

Do istoty tożsamości katechety należy także bycie nauczycielem i mistagogiem. Katecheta jest wezwany do otwierania człowieka na prawdę i jego ostateczne powołanie, poprzez zaznajamianie go z Chrystusem, wprowadzanie go do rozmaitych wymiarów chrześcijańskiego życia, odkrywanie przed nim tajemnic zbawienia, zawartych $\mathrm{w}$ depozycie wiary i urzeczywistniających się w liturgii Kościoła ${ }^{46}$. W ramach formacji Autorzy Dyrektorium umieszczają te zadania w wymiarze „wiedzieć”. Katecheta ma posiadać konkretną wiedzę, którą zapewnia mu formacja biblijnoteologiczna oraz znajomość człowieka i kontekstu społecznego. W jego formacji należy kłaść nacisk na pogłębienie wiedzy i studiowanie przesłania chrześcijańskiego, którego przekaz powinien uwzględniać eklezjalny, kulturowy, i egzystencjalny kontekst adresata. Pogłębienie wiedzy odbywa się, zdaniem autorów dyrektorium, poprzez zażyłość z Pismem Świętym, studiowanie Katechizmu Kościoła Katolickiego, dokumentów Nauczycielskiego Urzędu Kościoła oraz katechizmów Kościołów partykularnych ${ }^{47}$. Aby katecheta był nauczycielem i mistagogiem konieczne jest nie tylko dochowanie wierności przesłaniu wiary, ale także poznanie konkretnego człowieka i jego kontekstu społecznego. Wiedzę tę uzyskuje nie tylko przez doświadczenie i namysł nad nim, ale także przez cenny wkład nauk humanistycznych. Formacja katechetów powinna zatem uwzględniać m.in. pedagogię, psychologię, socjologię, pedagogikę i nauki o komunikacji społecznej. Niemniej odpowiedzialni za formację katechetów powinni wziąć pod uwagę także kryteria określające rolę nauk humanistycznych w formacji katechetów ${ }^{48}$. Autorzy dyrektorium wśród kryteriów tych wymieniają: „poszanowanie autonomii nauk (...), rozeznanie i ocena różnych teorii psychologicznych, socjologicznych i pedagogicznych, pozwalające docenić ich wartość i rozpoznać ograniczenia"49. Ich zdaniem, należy pamiętać, aby wkład nauk humanistycznych przyjmowany był w perspektywie wiary oraz w oparciu o chrześcijańską antropologię $e^{50}$.

Bycie towarzyszem i wychowawcą tych, których Kościół powierza katechecie to kolejne, ostatnie wyzwanie, w kontekście którego najnowsze dyrektorium podejmuje tematykę tożsamości i formacji katechety. Katecheta ma być „ekspertem w sztuce

\footnotetext{
45 DK 139.

46 Pod. DK 113.

47 Por. DK 143.

48 Por. DK 146.

49 DK 147

50 Por. tamże.
} 
towarzyszenia”, ma posiadać umiejętności wychowawcze, umieć słuchać i wnikać w dynamikę dojrzewania człowieka, cierpliwie i stopniowo stawać się „towarzyszem podróży", pomagając katechizowanym dojrzewać w życiu chrześcijańskim i jednocześnie podążać z nimi w stronę Boga ${ }^{51}$. Autorzy Dyrektorium umieszczają te zadania w wymiarze „umiejętności działania”, realizującym się poprzez formację pedagogiczną i metodologiczną. Formacja ta ma na celu wypracowanie takich postaw, jak: „wewnętrzna wolność i bezinteresowność, oddanie i spójność, pozwalające być wiarygodnym świadkiem wiary (...), umiejętność przekazywania wiary i opowiadania o niej tj. umiejętność żywego przedstawiania historii zbawienia tak, by rozmówcy czuli się jej częścią, (...) wykształcenie mentalności wychowawczej, która pociąga ze sobą gotowość do budowania dojrzałych relacji z innymi i zdolność do prowadzenia grupy w taki sposób, aby rozbudzać zarówno indywidualne, jak i wspólnotowe procesy uczenia się, (...) spokojne układanie relacji wychowawczych w ich wymiarze uczuciowym, (...) umiejętność opracowania drogi rozwijania wiary, polegająca na uwzględnianiu okoliczności społeczno-kulturalnych; opracowaniu realistycznego planu działania; kreatywnym korzystaniu z języków, technik i narzędzi oraz ocenie wyników tego procesu" ${ }^{\text {"2 }}$. Istotnym aspektem w kształtowaniu w sobie takich postaw jest świadomość katechety, że uczestniczy w realizacji procesu wychowawczego nie indywidualnie, ale wraz ze wspólnotą Kościoła i w jej imieniu. Dlatego powinien potrafić pracować $\mathrm{w}$ jedności, a zatem konfrontować się z zespołem katechetów oraz innymi osobami zaangażowanymi w duszpasterstwo ${ }^{53}$. Ogromną pomocą w tej kwestii niewątpliwie jest stała formacja odbywająca się w ramach diecezji, gdzie katecheci nie tylko mają możliwość pogłębiać teoretyczną znajomość problemów pedagogicznych i katechetycznych, ale także mogą doskonalić własne doświadczenia zawodowe oraz mają możliwość wzajemnej wymiany doświadczeń. Programy takiej formacji - przygotowywane przez Wydziały Nauki Katolickiej poszczególnych diecezji - stanowią ważną część diecezjalnego planu katechetycznego. Zazwyczaj przyjmują one formę szkoleń, seminariów metodycznych, warsztatów, otwartych lekcji, konferencji katechetycznych czy sympozjów.

Tożsamość i formacja katechetów zawsze stanowiła przedmiot troski i pogłębionej analizy Kościoła. Wszystkie dokumenty katechetyczne wyraźnie podkreślają, że istotą tożsamości jest przede wszystkim odkrycie i przyjęcie powołania przez katechetę. Tylko wówczas będzie on w stanie podejmować wyzwania i zadania, jakie stawia przed nim Kościól, powierzając mu dzieło katechizacji. Ma on przecież być nauczycielem, mistagogiem, wychowawcą, apostołem i ewangelizatorem. Powinien być człowiekiem dojrzałym, prowadzącym pogłębione życie duchowe, posiadającym wiedzę z zakresu teologii oraz nauk humanistycznych. Ma być towarzyszem, strażnikiem pamięci o Bogu, a nade wszystko świadkiem. Swoim życiem

51 Por. DK 113.

52 DK 149.

53 Por. DK 150. 
ma świadczyć, że wierzy w to, czego naucza, że sam doświadcza głębokiej relacji z Bogiem, że dba o tę relację i że stanowi ona sens jego życia. Tylko wówczas będzie potrafił odczytywać znaki czasu i dostosować swój przekaz do zmieniających się warunków i przemian społeczno-kulturowych oraz doprowadzać katechizowanych do ich osobistego spotkania z Bogiem.

Słowa klucze: katecheta, tożsamość, formacja, dyrektoria, katecheza.

\section{Summary}

The identity and formation of the catechist feature prominently in the catechetical documents of the Church. The article presents the most significant aspects of the Church's teaching as reflected in the directories between 1971 and 2020. All the catechetical documents emphasize that the discovery and acceptance of the vocation lie at the heart of the catechist's identity. Thus the recent directories for catechesis give special consideration to who the catechist is, who they should become, who they are not, and how they differ from other persons engaged in pastoral work. First, the notion of identity and its relation to formation is examined and is followed by a historical outline of the documents under discussion and their particular references to the identity and formation of catechists. The paper ends with briefly stated conclusions.

Keywords: catechist, identity, formation, directories, catechesis.

\section{Riassunto}

Le questioni dell'identità e della formazione del catechista occupano un posto importante nei documenti catechetici della Chiesa. Questo articolo si prendono in disamina gli aspetti più importanti dell'insegnamento della Chiesa contenuti nei Direttori dal $1971 \mathrm{al}$ 2020. Tutti i documenti catechistici mettono in rilievo che l'essenza dell'identità consiste soprattutto nella scoperta e nell'accoglienza della vocazione da parte del catechista. Da qui il tentativo di rispondere alle domande su chi è e chi non è il catechista, chi dovrebbe diventare e come si differenzia dalle altre persone impegnate nelle attività pastorali, tutto ciò rappresenta il tema speciale degli ultimi Direttori catechetici. In primo luogo, verrà analizzata la nozione di identità e il suo rapporto con la nozione di formazione. Verrà quindi presentato un breve cenno storico dei documenti discussi e dei loro riferimenti specifici all'identità e alla formazione dei catechisti. Tutto si conclude con un breve riepilogo.

Parole chiavi: catechista, identità, formazione, direttore, catechesi.

\section{Bibliografia}

Encyklopedia katolicka, t. XIX, Gigilewicz E. (red.), Katolicki Uniwersytet Lubelski Jana Pawła II, Lublin 2013.

Finke M., Pedagogika wiary, Poznań 1996.

Frejusz K., Katecheta wobec reformy oświaty - „być, wiedzieć, umieć działać”, w: Kowalczyk J., Rayzacher-Majewska A. (red.), Idźmy naprzód z nadzieja!! Katechetyczne aspekty reformy oświaty, Diecezjalne Centrum Edukacyjne, Legnica 2017, s. 53-69. 
Gogolik M., Znaczenie formacji duchowej w procesie posługi słowa, „Pedagogia Ojcostwa”, 1(2010), s. 230-243.

Kiciński A., Formacja katechety na wzór Samuela, w: Kulpaczyński S. (red.), Miejsca katechezy. Rodzina, parafia, szkoła, Lublin 2005, s. 347-363.

Kiciński A., Rozwój dyrektoriów katechetycznych po Soborze Watykańskim II (1971-1997-2020), „Roczniki Teologiczne” 67(2020)11, s. 5-27.

Marek Z., Katecheza Kościoła w świetle Dyrektorium ogólnego o katechizacji, „Collectanea Theologica" 68(1998)3, s. 163-181.

Mendyk M., Katecheta-nauczyciel, wychowawca, świadek. Jego misja w warunkach nowej ewangelizacji, „Legnickie Studia Teologiczno-Historyczne” 10(2007), s. 105-119.

Misiewicz J., Tożsamość katechety a skuteczność przepowiadania wiary, „Wrocławski Przegląd Teologiczny" 5(1997)2, s. 115-120.

Panuś T., Geneza i główne wskazania Dyrektorium ogólnego o katechizacji z 1997, „Studia Katechetyczne" 13(2017), s. 11-33.

Smoleń J., Formacja ludzka katechetów, „Paedagogia Christiana” 2(2009)24, s. 151-162.

Szewczyk R., Osobowość nauczyciela religii, „Studia Katechetyczne” 7(2010), s. 217-234.

Szewczyk R., Tożsamość katechety w świetle dokumentów Kościoła w latach 1965-1991, Warszawa 1996.

Waszczyńska K., Wokót problematyki tożsamości, „Rocznik Towarzystwa Naukowego Płockiego" 6(2014), s. 48-73. 